\title{
Description and Molecular Phylogeny of a Novel Hypotrich Ciliate from the Soil of Marche Region, Italy; Including Notes on the MOSYSS Project
}

\author{
Daizy Bharti ${ }^{a}$, Santosh Kumar ${ }^{a, b}$ \& Antonietta La Terza ${ }^{a}$ \\ a School of Biosciences and Veterinary Medicine, Laboratory of Animal and Molecular Ecology, University of Camerino, Via Gentile III da Varano, \\ Camerino 62032, MC, Italy \\ b Department of Biological Sciences, College of Natural Sciences, University of Ulsan, Ulsan 44610, South Korea
}

\section{Keywords \\ Bioindicators; organic farm; Rigidocortex quadrinucleatus n. sp.; soil ciliates; SSU rRNA gene. \\ Correspondence \\ S. Kumar and A. La Terza, School of \\ Biosciences and Veterinary Medicine, University of Camerino, Via Gentile III da Varano, Camerino 62032, (MC), Italy Telephone number: +39-0737-403272; FAX number: +39-0737-403290; e-mails: santoshcbio@gmail.com (S.K.) and antonietta.laterza@unicam.it (A.L.T.)}

Received: 9 September 2016; revised 31 January 2017; accepted February 8, 2017.

doi:10.1111/jeu.12404

\section{ABSTRACT}

The morphology and morphogenesis during cell division of a new stylonychine hypotrich, Rigidocortex quadrinucleatus n. sp., were investigated using live observation and protargol staining. The new species was isolated from soil samples collected from an organic farm in the Marche Region, Italy, in framework of the MOSYSS project. Rigidocortex quadrinucleatus is characterized as follows: cell size about $180 \times 80 \mu \mathrm{m}$ in vivo; four ellipsoidal macronuclear nodules; 44 adoral membranelles: 18 fronto-ventral-transverse cirri consisting of three frontal, four frontoventral, one buccal, three ventral, two pretransverse, and five transverse cirri; dorsal kinety 3 with multiple fragmentation; resting cyst with hyaline ridges. Rigidocortex quadrinucleatus mainly differs from the type species $R$. octonucleatus in having four (vs. eight) macronuclear nodules. Rigidocortex quadrinucleatus can be easily confused with Sterkiella cavicola since both have a rather similar ventral ciliature; however, they can be separated by the slightly higher number of cirri in the left marginal row that runs along the posterior cell's margin in R. quadrinucleatus. Morphogenesis on the ventral surface is highly similar to that of Sterkiella species, but differs significantly on the dorsal surface (multiple vs. simple fragmentation of dorsal kinety 3). Phylogenetic analyses based on SSU rRNA gene sequences consistently place the new species within the stylonychine oxytrichids, clustering closer to Gastrostyla steinii than to S. cavicola.
THE genus Rigidocortex Berger, 1999 was established for Australocirrus octonucleatus Blatterer and Foissner, 1998 because it differs significantly from the type species A. oscitans Blatterer and Foissner, 1988 in body flexibility. Furthermore, it was observed that during morphogenesis in $A$. oscitans cirrus $V / 3$ is involved in anlagen formation, supporting the classification in the Oxytrichinae. On the contrary, A. octonucleatus is rigid, showing that it is not a sister taxon of $A$. oscitans. Considering these differences, however, in the absence of ontogenetic data, Berger (1999) transferred A. octonucleatus to Rigidocortex with multiple fragmentation of dorsal kinety 3 as an autapomorphy (Berger 1999). The ontogenetic and molecular data for the monotypic genus Rigidocortex are unknown.

This study describes a novel soil species of the genus Rigidocortex, R. quadrinucleatus n. sp., isolated from the
Marche Region, Italy. Rigidocortex quadrinucleatus possesses a unique combination of morphological features that separates it from the type species. Similarity in the ventral ciliature of the new species with Sterkiella cavicola (Kahl, 1935) Foissner et al., 1991 initially compelled us to classify it in the genus Sterkiella, however, detailed ontogenetic data on the dorsal surface, i.e., multiple fragmentation of dorsal kinety 3 , demanded the classification of the new species in Rigidocortex. A detailed description of its morphology and first record on the morphogenesis and phylogenetic analyses based on SSU rRNA gene sequence data for the genus is presented. Furthermore, this study is the second report on the identification of a novel soil ciliate species in the framework of the MOSYSS (MOnitoring SYstem of Soils at multiScale) project, Marche Region (Kumar et al. 2014; Tiberi et al. 2014). 


\section{MATERIALS AND METHODS}

\section{Description of the 209BIO sampling site and sample processing}

The 209BIO sampling site $\left(43^{\circ} 19^{\prime} 2.31 " \mathrm{~N}\right.$; $\left.13^{\circ} 27^{\prime} 51.89^{\prime \prime} \mathrm{E}\right)$ represents one of the 30 sites selected in the frame of the MOSYSS project for monitoring the health of agricultural soils of the Marche Region, Italy. For details on the sampling site and the project, see "Type locality", "Occurrence and Ecology" and "Notes on the MOSYSS project".

Soil samples $(0-10 \mathrm{~cm}$ depth) were collected in May 2013, following the methodology described in Bharti et al. (2015). Main chemical-physical parameters $(\mathrm{pH}$, moisture, temperature) were measured at the 209BIO site, using a soil pH meter (PH-212; Lutron, London, U.K.), a moisture meter (PMS-714 Lutron), and a thermometer (HI-98501; Hanna Instruments, Milan, Italy), respectively. Soil texture analyses and further chemical analyses were performed at the laboratory of Agrochemistry of ASSAM (Agenzia per i Servizi nel Settore Agroalimentare delle Marche, http:// www.assam.marche.it) as described in Kumar et al. (2014).

Ciliates were reactivated from resting cysts from 1month-dried soil samples (approximately $300 \mathrm{~g}$ ) by employing the nonflooded Petri dish method (Foissner 1987). Live observations were made using a microscope with bright-field illumination. The protargol staining method described by Kamra and Sapra (1990) was used with some modifications to reveal the infraciliature. Measurements of impregnated specimens were performed at a magnification of 1,000X using the Optika Vision Lite software. An Optika microscope camera was employed for photomicrography. Images were focus-stacked using the image stacking software CombineZP (Hadley 2010). The illustration of the live specimen was prepared using freehand sketches, while those of impregnated specimens were made with a drawing device. Terminology is according to Berger (1999) and Wallengren (1900).

\section{DNA extraction, PCR amplification, and sequencing}

Five cells (same culture was used for live observation and protargol staining to study morphology and morphogenesis) were collected from a nonflooded Petri dish culture with the help of glass micropipettes and washed three times with autoclaved distilled water. Genomic DNA was extracted as per the protocol for Norgen DNA Kit (Elettrofor Scientific Instruments, Borsea, Italy). Extracted DNA $(5 \mu l)$ was dispensed into a PCR tube containing $5 \mu$ of distilled water, and amplifications were carried out using high-fidelity $P f \times 50^{T M}$ DNA polymerase (Invitrogen S.r.l., San Giuliano Milanese, Italy) in a total volume of $50 \mu$ l with the universal eukaryotic primers Euk A (FW 5'AACCTGGTTGATCCTGCCAGT-3') and Euk B (RV 5'TGATCCTTCTGCAGGTTCACCTAC-30) (Medlin et al.1988). In addition, nested primer pairs Eup 18S (FW 5'-TAG AGG GAC TTT GTG TGC AAC C-3') and Eup 18S (RV 5'-ATC TCC CTG AAA CAC ACG TTG G-3') were used in combination with the universal primers for amplification and sequencing. The PCR program for $18 S$ rDNA amplification included an initial denaturation at $94{ }^{\circ} \mathrm{C}$ for $3 \mathrm{~min}$, followed by 35 cycles of $94{ }^{\circ} \mathrm{C}$ for $1 \mathrm{~min}, 55{ }^{\circ} \mathrm{C}$ for $45 \mathrm{~s}$, and $72{ }^{\circ} \mathrm{C}$ for $80 \mathrm{~s}$, with a final extension step at $72{ }^{\circ} \mathrm{C}$ for $10 \mathrm{~min}$. After confirmation of the appropriate size, the PCR products were purified using the Nucleospin gel extraction kit (Qiagen S.r.l., Milan, Italy) and were then directly sequenced on both strands at StarSEO GMBH, Germany.

\section{Phylogenetic analyses}

For phylogenetic analyses, the SSU rRNA gene sequence of $R$. quadrinucleatus $\mathrm{n}$. sp. was aligned with $53 \mathrm{SSU}$ rRNA sequences of hypotrich ciliates from GenBank using the MAFFT 7.047 software (choosing the iterative refinement methods Q-INS-I which considers the secondary structure of RNA) (Katoh and Standley 2013).

Ambiguously aligned regions were identified and excluded from the phylogenetic analyses with GBlocks v.0.91b (Castresana 2000) using parameters optimized for rRNA alignments (minimum length of A block $=5$, allowed gap positions = with half), leaving 1,679 unambiguously aligned positions. The final alignment was then used for subsequent phylogenetic analyses after converting the FASTA (.fas) file to NEXUS (.nex) format using the open web-based tool ALTER (Alignment Transformation EnviRonment) (Glez-Peña et al. 2010). A Bayesian inference (BI) analysis was performed using Mr.Bayes v.3.2.1 (Ronquist and Huelsenbeck 2003) and the GTR + I + G model, as selected by the jModel Test v.2.1.3 software (Posada 2008) under the Akaike Information Criterion corrected ( $\mathrm{AIC}$ ). Markov chain Monte Carlo (MCMC) simulations were run, with two sets of four chains using the default settings, for $10,000,000$ generations with trees sampled every 100 generations and discarding the first $25 \%$ of the sampled trees as burn-in. The remaining trees were used to generate a consensus tree and to calculate the posterior probabilities (PP) of all branches using the majority-rule consensus approach.

The previous alignment was also used to perform a Maximum Likelihood (ML) tree by means of the Molecular Evolutionary Genetic Analysis (MEGA) software, v.5.2.2 (Tamura et al. 2011) using the default parameters and the GTR + I + G model. The reliability of tree topology was assessed by 1,000 bootstrap replicates and was expressed as a percentage. Phylogenetic trees were visualized using the free software package FigTree $v 1.4$ by A. Rambaut at http://tree.bio.ed.ac.uk/software/figtree/.

\section{RESULTS}

\section{Description of Rigidocortex quadrinucleatus $\mathrm{n}$. $\mathrm{sp}$}

Size in vivo $155-215 \times 65-90 \mu \mathrm{m}$, usually about $180 \times 80 \mu \mathrm{m}$, as calculated from in vivo measurements $(n=25)$ and morphometric data in Table 1, assuming $15 \%$ preparation shrinkage. Body outline ellipsoidal to elongate 
Table 1. Morphometric data on Rigidocortex quadrinucleatus n. sp.

\begin{tabular}{|c|c|c|c|c|c|c|c|c|}
\hline Characteristic $^{a}$ & Mean & M & SD & SE & $\mathrm{CV}$ & Min & Max & $n$ \\
\hline Body, length & 154.2 & 151.0 & 14.4 & 3.1 & 9.3 & 135.0 & 186.0 & 21 \\
\hline Body, width & 70.2 & 70.0 & 5.3 & 1.2 & 7.6 & 58.0 & 79.0 & 21 \\
\hline Body length:width, ratio & 2.2 & 2.2 & 0.2 & 0.1 & 10.5 & 1.9 & 2.8 & 21 \\
\hline Body width:length, percentage & 45.8 & 46.4 & 4.6 & 1.0 & 10.1 & 36.0 & 53.7 & 21 \\
\hline Anterior body end to proximal end of adoral zone, distance & 69.5 & 69.0 & 4.0 & 0.9 & 5.7 & 63.0 & 78.0 & 21 \\
\hline Body length:AZM length, ratio & 2.2 & 2.2 & 0.2 & 0.0 & 7.7 & 2.0 & 2.6 & 21 \\
\hline Anterior body end to proximal end of adoral zone, \% of body length & 45.3 & 44.9 & 3.4 & 0.7 & 7.4 & 39.0 & 50.0 & 21 \\
\hline Adoral membranelles, number & 44.1 & 44.0 & 1.8 & 0.4 & 4.1 & 41.0 & 47.0 & 21 \\
\hline Adoral membranelles, width of longest base & 14.7 & 15.0 & 1.1 & 0.2 & 7.5 & 13.0 & 17.0 & 21 \\
\hline Anterior body end to paroral membrane, distance & 14.0 & 14.0 & 2.1 & 0.5 & 14.9 & 8.0 & 18.0 & 21 \\
\hline Paroral membrane, length & 45.0 & 45.0 & 1.8 & 0.4 & 4.1 & 41.0 & 47.0 & 21 \\
\hline Anterior body end to endoral membrane, distance & 17.0 & 18.0 & 2.0 & 0.4 & 11.8 & 11.0 & 20.0 & 21 \\
\hline Endoral membrane, length & 48.4 & 49.0 & 1.5 & 0.3 & 3.2 & 45.0 & 50.0 & 20 \\
\hline Anterior body end to anterior macronuclear nodule, distance & 40.9 & 40.0 & 5.8 & 1.3 & 14.3 & 33.0 & 52.0 & 21 \\
\hline Macronuclear figure, length & 75.7 & 77.0 & 6.4 & 1.4 & 8.4 & 60.0 & 89.0 & 21 \\
\hline Anteriormost macronuclear nodule, length & 19.2 & 19.0 & 2.3 & 0.5 & 12.0 & 14.0 & 24.0 & 21 \\
\hline Anteriormost macronuclear nodule, width & 13.1 & 13.0 & 1.3 & 0.3 & 9.7 & 11.0 & 16.0 & 21 \\
\hline Macronuclear nodules, number & 4.0 & 4.0 & 0.0 & 0.0 & 0.0 & 4.0 & 4.0 & 21 \\
\hline Anteriormost micronucleus, length & 3.9 & 4.0 & 0.3 & 0.1 & 7.7 & 3.0 & 4.0 & 21 \\
\hline Anteriormost micronucleus, width & 3.7 & 4.0 & 0.5 & 0.1 & 13.2 & 3.0 & 4.0 & 21 \\
\hline Micronuclei, number & 3.1 & 3.0 & 0.8 & 0.2 & 24.8 & 1.0 & 4.0 & 21 \\
\hline Anterior body end to right marginal row, distance & 34.9 & 34.0 & 6.1 & 1.3 & 17.5 & 29.0 & 52.0 & 21 \\
\hline Posterior body end to right marginal row, distance & 4.1 & 3.0 & 2.0 & 0.4 & 48.5 & 2.0 & 8.0 & 21 \\
\hline Right marginal row, number of cirri & 25.0 & 25.0 & 1.2 & 0.3 & 4.7 & 23.0 & 27.0 & 21 \\
\hline Posterior body end to left marginal row, distance & 1.2 & 1.0 & 0.4 & 0.1 & 33.8 & 1.0 & 2.0 & 21 \\
\hline Left marginal row, number of cirri & 27.1 & 27.0 & 1.4 & 0.3 & 5.0 & 23.0 & 29.0 & 21 \\
\hline Frontal cirri, number & 3.0 & 3.0 & 0.0 & 0.0 & 0.0 & 3.0 & 3.0 & 21 \\
\hline Anterior body end to buccal cirrus, distance & 32.1 & 32.0 & 2.6 & 0.6 & 8.1 & 28.0 & 38.0 & 21 \\
\hline Buccal cirrus, number & 1.0 & 1.0 & 0.0 & 0.0 & 0.0 & 1.0 & 1.0 & 21 \\
\hline Frontoventral cirri, number & 4.0 & 4.0 & 0.0 & 0.0 & 0.0 & 4.0 & 4.0 & 21 \\
\hline Postoral cirri, number & 3.2 & 3.0 & 0.6 & 0.1 & 19.3 & 3.0 & 5.0 & 21 \\
\hline Pretransverse cirri, number & 2.0 & 2.0 & 0.0 & 0.0 & 0.0 & 2.0 & 2.0 & 21 \\
\hline Posterior body end to rear transverse cirrus, distance & 16.4 & 15.0 & 4.4 & 1.0 & 26.9 & 9.0 & 24.0 & 21 \\
\hline Transverse cirri, number & 5.2 & 5.0 & 0.4 & 0.1 & 7.8 & 5.0 & 6.0 & 21 \\
\hline Dorsal kineties, number & 7.0 & 7.0 & 0.0 & 0.0 & 0.0 & 7.0 & 7.0 & 13 \\
\hline Dorsal kinety 1 , number of bristles & 45.3 & 46.0 & 3.9 & 1.1 & 8.6 & 37.0 & 51.0 & 13 \\
\hline Dorsal kinety 2, number of bristles & 36.2 & 37.0 & 2.1 & 0.6 & 5.9 & 31.0 & 39.0 & 13 \\
\hline Dorsal kinety 3 , number of bristles & 29.1 & 30.0 & 2.8 & 0.8 & 9.7 & 22.0 & 32.0 & 13 \\
\hline Dorsal kinety 4 , number of bristles & 8.3 & 8.0 & 2.2 & 0.6 & 26.6 & 5.0 & 13.0 & 13 \\
\hline Dorsal kinety 5, number of bristles & 27.9 & 28.0 & 2.5 & 0.7 & 8.8 & 23.0 & 31.0 & 13 \\
\hline Dorsomarginal row 1 , number of bristles & 15.5 & 15.0 & 1.5 & 0.4 & 9.7 & 13.0 & 18.0 & 13 \\
\hline Dorsomarginal row 2 , number of bristles & 8.2 & 8.0 & 1.3 & 0.4 & 15.7 & 6.0 & 11.0 & 13 \\
\hline Caudal cirri, number & 3.0 & 3.0 & 0.0 & 0.0 & 0.0 & 3.0 & 3.0 & 21 \\
\hline
\end{tabular}

${ }^{a}$ Data based on mounted, protargol-impregnated, and randomly selected specimens from a nonflooded Petri dish culture. Measurements in $\mu$ m. $\mathrm{CV}=$ coefficient of variation in \%; $\mathrm{M}=$ median; Max = maximum; Mean = arithmetic mean; Min = minimum; $n=$ number of individuals investigated; $\mathrm{SD}=$ standard deviation; $\mathrm{SE}=$ standard error of arithmetic mean.

ellipsoidal, both ends broadly rounded; dorsoventrally flattened about 2:1 (Fig. 1A, B, 2A-C, 3A-E and Table 1). Nuclear apparatus slightly left of midline, composed of four macronuclear nodules and one to four micronuclei (Fig. 2A, C, 3A-E and Table 1). Macronuclear nodules globular to broadly ellipsoidal, anteriormost nodule on average $19 \times 13 \mu \mathrm{m}$ in protargol preparations; contain many small globular nucleoli, 1-3 $\mu \mathrm{m}$ across. Micronuclei usually attached to or near to macronuclear nodules, globular, on average $4.0 \mu \mathrm{m}$ across in protargol preparations (Fig. 2A, C, $3 \mathrm{~A}-\mathrm{E}$ and Table 1). Contractile vacuole in mid-body (about $50 \%$ ) near left margin of cell (Fig. 1A). Cortex rigid, specific cortical granules absent. Cytoplasm colorless, filled with few crystals, cytoplasmic granules about 2-5 $\mu \mathrm{m}$ in diameter, and some fat droplets (Fig. 1A, B, 2A). Feeds on bacteria, small flagellates, and ciliates (Colpoda sp.) in nonflooded Petri dish culture. Swims and creeps rather rapidly (Fig. 1A, B, 2A). 

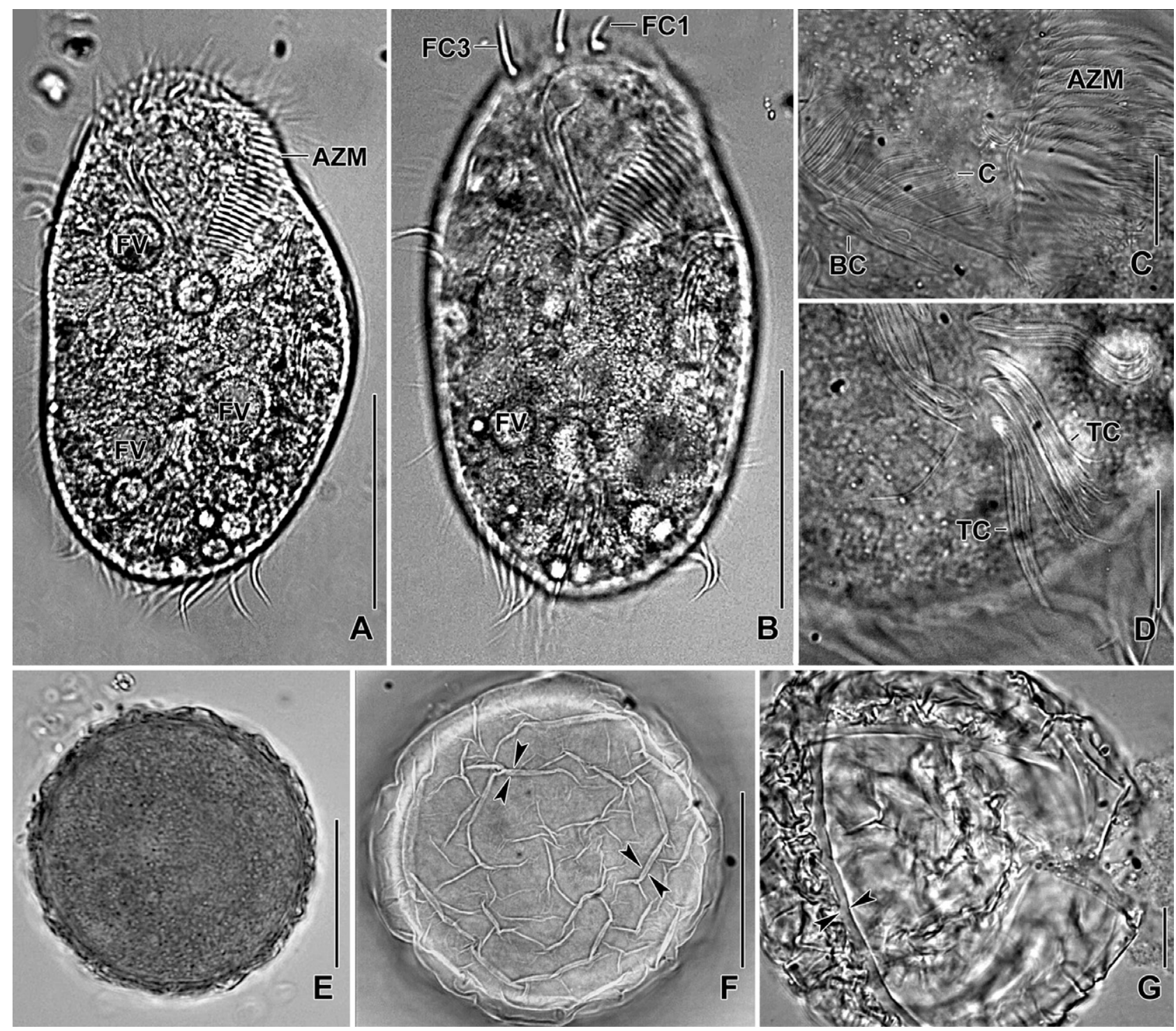

Figure 1 Photomicrographs of Rigidocortex quadrinucleatus from life. (A, B) Slightly compressed specimens due to cover slip pressure. (C, D) Top view, showing the paroral cilia (C) and transverse cirri (D). (E-G) Optical section of resting cyst (E), surface view showing the wrinkled hyaline ridges $(F)$, squeezed cyst $(G)$ showing cyst wall (opposed arrowheads). $A Z M=$ adoral zone of membranelles; $B C=$ buccal cirrus; $C=$ paroral cilia; FC (1, 3) = frontal cirri; FV = food vacuoles; TC = transverse cirri. Scale bars = $10 \mu \mathrm{m}(\mathrm{G}) ; 20 \mu \mathrm{m}(\mathrm{C}, \mathrm{D}) ; 35 \mu \mathrm{m}(\mathrm{E}, \mathrm{F})$; and $75 \mu \mathrm{m}(\mathrm{A}, \mathrm{B})$.

Cirral pattern and number of cirri of usual variability, except for the more varying number of postoral cirri (CV 19\%). Usually 18 fronto-ventral-transverse cirri (Fig. 2A, B, 3A-D and Table 1). Frontal cirri distinctly enlarged, in vivo about $20 \mu \mathrm{m}$ long, right cirrus left of distal end of adoral zone, middle cirrus anterior of buccal cirrus, left cirrus anterior of distal end of undulating membranes. Invariably, one slightly thickened buccal cirrus about $32 \mu \mathrm{m}$ from anterior body end. Constantly four $(n=21)$ frontoventral cirri, arranged in hook like pattern as in typical oxytrichids (Fig. 2A, B, 3A-D and Table 1). Usually three, rarely four or five (two of 21 specimens analyzed) postoral cirri and invariably two obliquely arranged pretransverse ventral cirri. Usually five, rarely six
(4 out of 21 specimens analyzed) distally fringed transverse cirri arranged in a hooked pattern, in vivo about $35 \mu \mathrm{m}$ long, rearmost cirrus about $16 \mu \mathrm{m}$ distant from posterior body end in protargol preparations (Fig. 1D, 2A, B, 3A-D and Table 1). Marginal cirri about $20 \mu \mathrm{m}$ long in protargol preparations. Left row reaches up to the posterior body end, composed of an average of 27 cirri; right row starts about $35 \mu \mathrm{m}$ from anterior body end, composed of an average of 25 cirri (Fig. 2A, B, 3A-D and Table 1).

On average seven dorsal kineties with bristles about 2$3 \mu \mathrm{m}$ long in protargol preparations. Kineties 1, 2 bipolar; kinety 3 slightly shortened posteriorly; kinety 4 short, bristles not aligned because consist of more or less two indistinct fragments; kinety 5 slightly shortened anteriorly; 


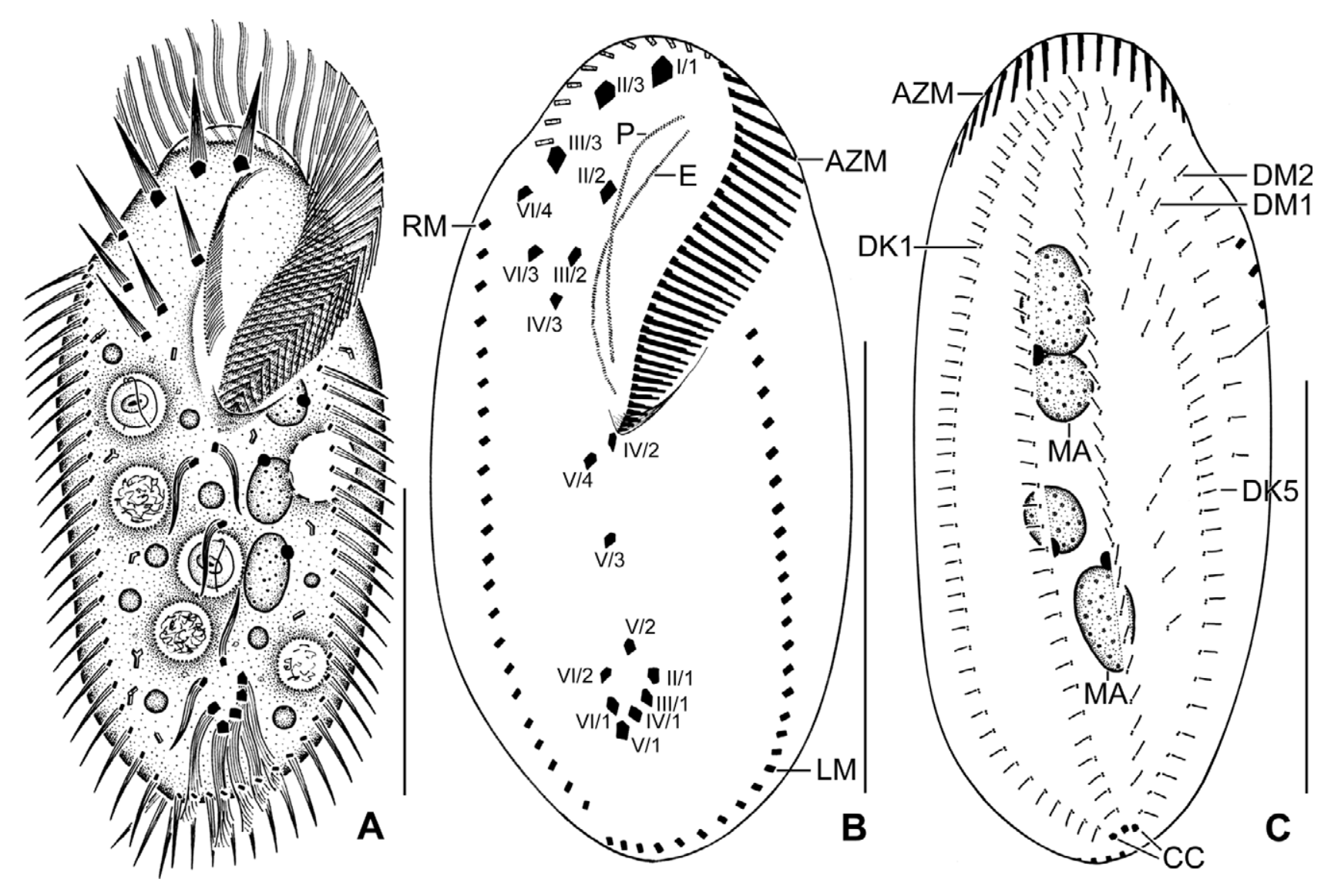

Figure 2 Line diagrams of Rigidocortex quadrinucleatus from life (A) and after protargol impregnation (B, C). (A) A representative cell with a length of $180 \mu \mathrm{m}$. (B, C) Ventral view of the holotype and dorsal view of a paratype specimen, showing the ciliature and the nuclear apparatus. AZM = adoral zone of membranelles; $C C=$ caudal cirri; DK1,5 = dorsal kineties; DM1,2 = dorsomarginal kineties; $E=$ endoral membrane; $L M=$ left marginal row; $\mathrm{MA}=$ macronuclear nodules; $\mathrm{P}=$ paroral membrane; $\mathrm{RM}=$ right marginal row; $I / 1, I I / 3, I I I / 3$, frontal cirri; $I I / 2$, buccal cirrus; III/2, IV/3, VI/3, VI/4, fronto-ventral cirri; IV/2, V/4, V/3, postoral ventral cirri; V/2, VI/2, pretransverse ventral cirri; II/1, III/1, IV/1, V/1, VI/1, transverse cirri. Scale bars $=80 \mu \mathrm{m}(\mathrm{A})$; and $75 \mu \mathrm{m}(\mathrm{B}, \mathrm{C})$.

kineties 6 and 7 terminate ahead of mid-body (Fig. 2C, 3E and Table 1). Three narrowly spaced caudal cirri at posterior margin of the cell, inconspicuous because not distinctly longer than marginal cirri (Fig. 2C, 3E and Table 1).

Adoral zone occupies about $45 \%$ of body length, composed of 44 membranelles on average, cilia about $30 \mu \mathrm{m}$ long in vivo (Fig. 1A, B, 2A, B, 3A-D and Table 1). Largest membranellar bases about $15 \mu \mathrm{m}$ wide in protargol preparations. Buccal cavity large and deep; buccal lip narrow covers proximal adoral membranelles. Undulating membranes in body's midline, moderately curved, intersect optically near mid-region. Paroral about $45 \mu \mathrm{m}$ long, commences about $14 \mu \mathrm{m}$ from anterior body end, cilia about $20 \mu \mathrm{m}$; endoral about $48 \mu \mathrm{m}$ long, commences about $3 \mu \mathrm{m}$ posterior of anterior end of paroral (Fig. 1A-C, 2A, B, 3A-D and Table 1).

\section{Resting cyst}

Two-week old resting cysts about $70 \mu \mathrm{m}$ across in vivo; cyst surface with hyaline ridges, about 2-3 $\mu \mathrm{m}$ high
(Fig. 1E-G). Cyst wall about $2 \mu \mathrm{m}$ thick. Cyst content composed of lipid droplets and separate macronuclear nodules (Fig. 1E-G).

\section{Morphogenesis}

Divisional morphogenesis is in the typical Sterkiella pattern (Foissner and Berger 1999; Foissner et al. 2002). The parental adoral zone of membranelles is retained unchanged for the proter while that of the opisthe is formed from the oral primordium that originates close to transverse cirrus $\| / 1$ (Fig. 4A-G, 5A-C). Five parental cirri (II/2, III/2, IV/2, IV/3, and $V / 4$ ) and the paroral and endoral are involved in the formation of six primordial streaks. Postoral ventral cirrus V/3 is not involved in the primordia formation (Fig. 4A-D, 5A). The 18 frontal-ventral-transverse cirri arise from these primordia, splitting in a 1, 3, 3, 3, 4, 4 pattern. The marginal primordia arise at each of two levels by "within-row" primordia formation; it elongates utilizing four or five parental cirri and differentiates into new marginal rows. The rest of the parental marginal cirri is resorbed (Fig. $4 \mathrm{C}-\mathrm{G}, 5 \mathrm{~A}-\mathrm{C}$ ). 

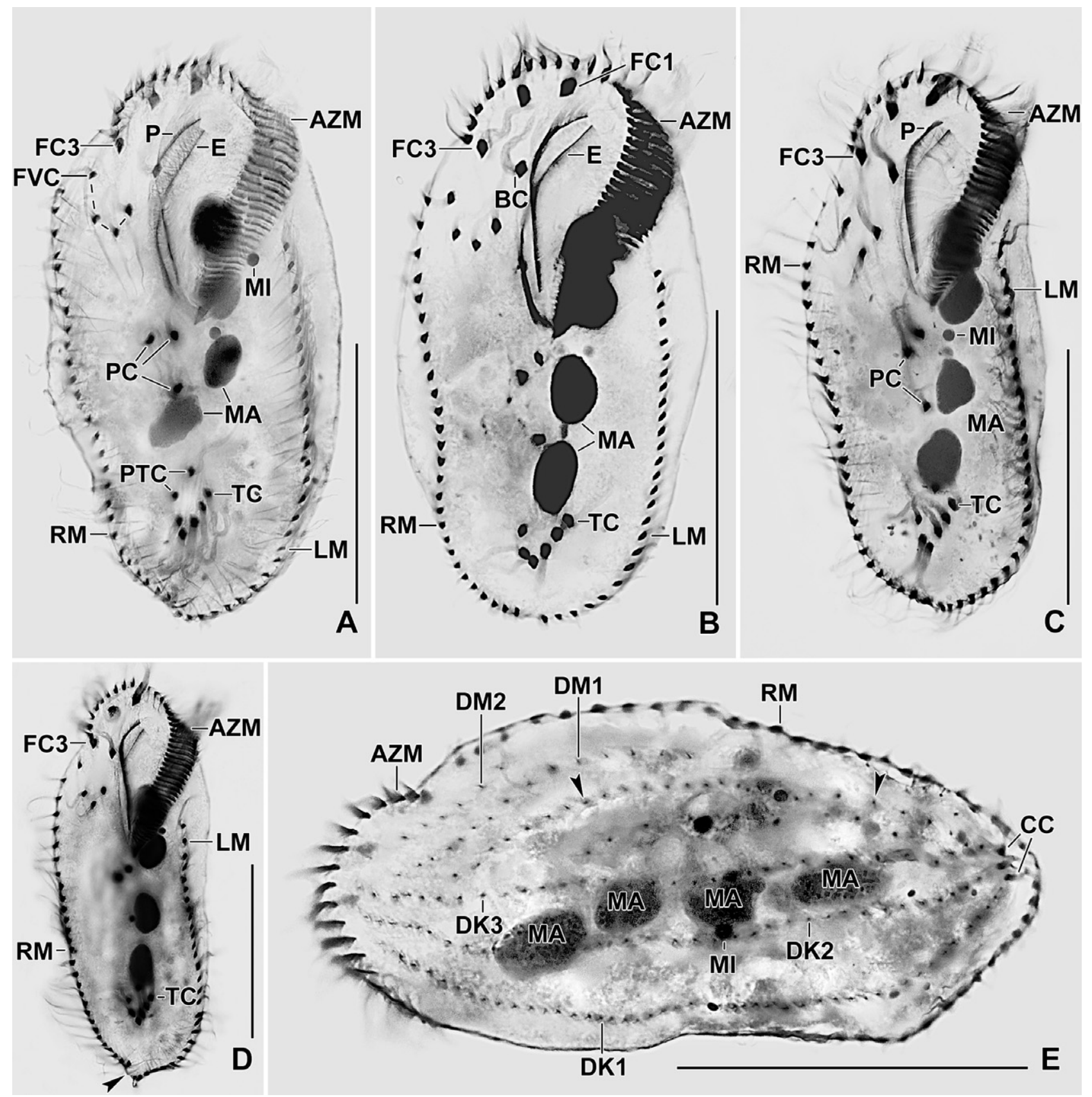

Figure 3 Photomicrographs of Rigidocortex quadrinucleatus after protargol impregnation. (A-D) Paratype specimens, showing body shape, nuclear apparatus, and ciliature on the ventral surface. Note that few specimen with a posterior indent (arrowhead) were also recorded (D). (E) Dorsal view of paratype specimen. Note the loose dikinetids between kinety 3 and 5 and narrowly spaced caudal cirri at the posterior body end. Arrowheads point to the right most fragment associated with caudal cirrus. $A Z M=$ adoral zone of membranelles; $B C=$ buccal cirrus; $C C=$ caudal cirri; $D K 1-3=$ dorsal kineties; $D M 1,2=$ dorsomarginal kineties; $E=$ endoral membrane; $F C(1,3)=$ frontal cirri; $F V C=$ frontoventral cirri; $\mathrm{LM}=$ left marginal row; $\mathrm{MA}=$ macronuclear nodules; $\mathrm{MI}=$ micronuclei; $\mathrm{P}=$ paroral membrane; $\mathrm{PC}=$ postoral cirri; $\mathrm{PTC}=$ pretransverse cirri; $\mathrm{RM}=$ right marginal row; $\mathrm{TC}=$ transverse cirri. Scale bars $=75 \mu \mathrm{m}$.

On the dorsal surface, three primordia are formed within dorsal kineties 1, 2, and 3 at two levels (one set for the proter and one for the opisthe) (Fig. 5A). The third dorsal primordium forms multiple fragments at the middle giving rise to the third, fourth, and fifth kinety. The loose dikinetids between kineties 3 and 5 make a single row in the vegetative cells. The two dorsomarginal rows arise near the right marginal row (Fig. 5A-F, 6D-F). One caudal cirrus each originates at the posterior end of the new dorsal kineties 1, 2, and 5. The caudal cirri are located in the gap between the posterior end of the left and the right marginal rows (Fig. 5A-F, 6D-F). 


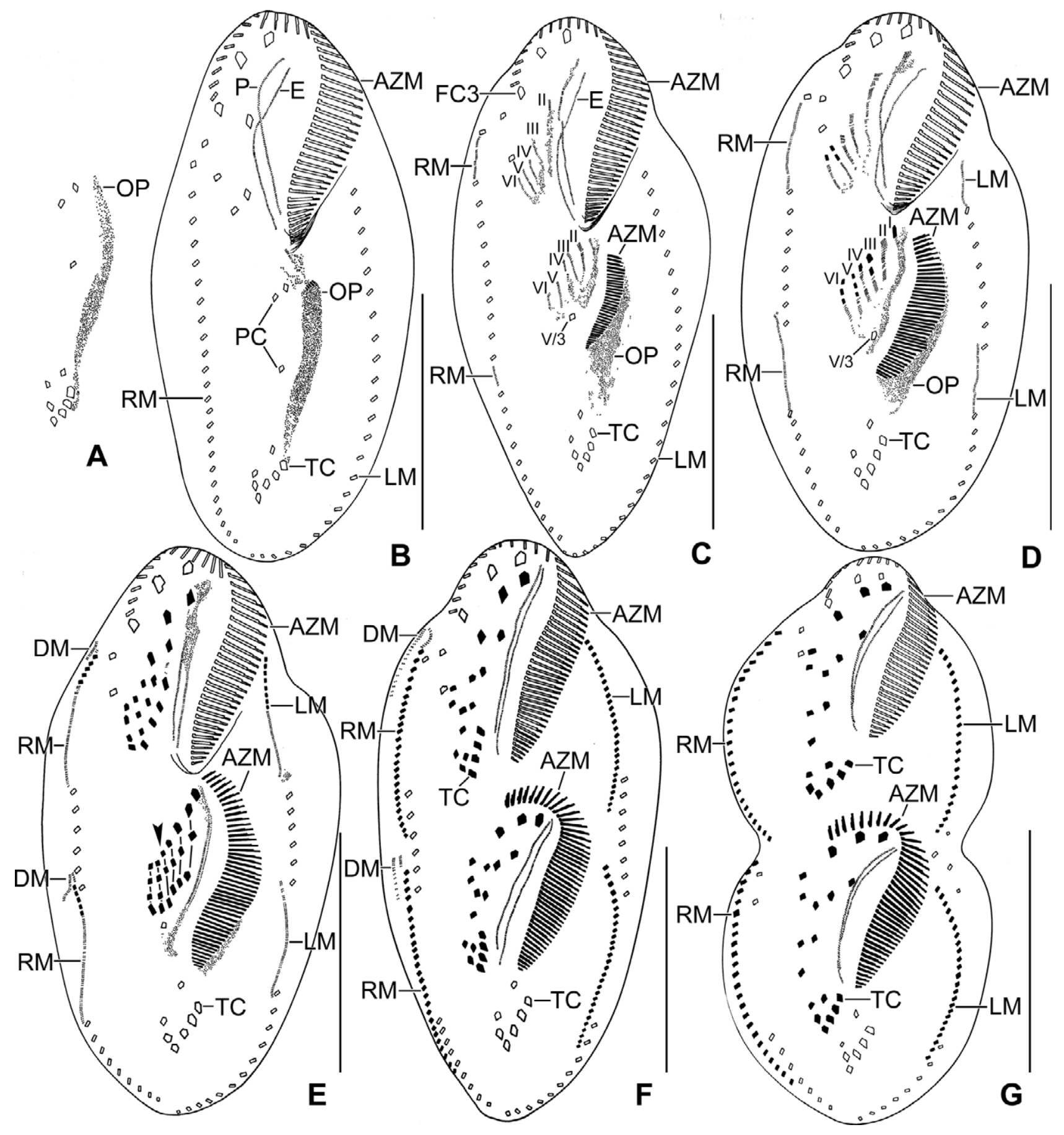

Figure 4 Line diagrams of protargol stained early $(\mathbf{A}-\mathbf{D})$, middle $(\mathbf{E})$, late dividers $(\mathbf{F}, \mathbf{G})$ of Rigidocortex quadrinucleatus. (A) Oral primordium develops close to transverse cirri. (B-D) Five parental cirri (II/2, III/2, IV/2, IV/3, and V/4) disaggregate to give rise to five fronto-ventral-transverse anlagen for proter and opisthe. Cirrus $V / 3$ does not participate in anlagen formation. (E-G) The newly formed fronto-ventral-transverse cirri migrate to their specific sites and dorsomarginal kineties develop close to the right marginal row. Arrowhead in (E) points to the additional anlage which forms extra postoral ventral and transverse cirri in vegetative specimen. A specimen (E) with additional anlage (arrowhead) which forms extra postoral ventral and transverse cirri. $A Z M=$ adoral zone of membranelles; $D M=$ dorsomarginal kineties; $E=$ endoral membrane; FC3 = frontal cirrus 3; $\mathrm{LM}=$ left marginal row; $\mathrm{OP}=$ oral primordium; $\mathrm{P}=$ paroral membrane; $\mathrm{PC}=$ postoral cirri; $\mathrm{RM}=$ right marginal row; $\mathrm{V} / 3=$ postoral ventral cirri; $\mathrm{I}-\mathrm{VI}=$ cirral anlagen. Scale bars $=75 \mu \mathrm{m}$. 


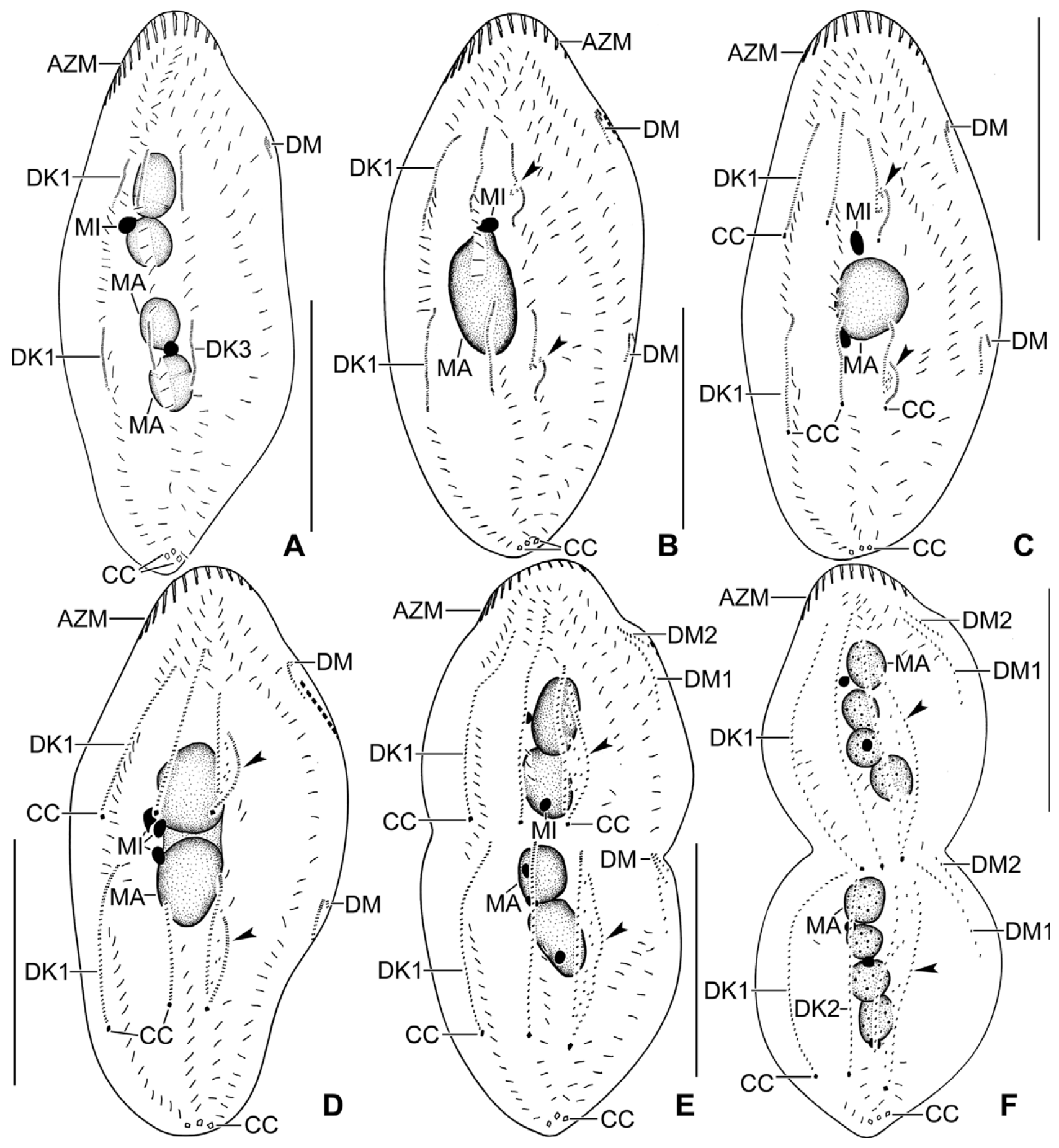

Figure 5 Line diagrams of protargol stained early (A), middle (B, C), late dividers (D-F) of Rigidocortex quadrinucleatus, showing the details of the event on the dorsal surface with respect to the nuclear division. (A) Within row formation of the anlagen for dorsal kineties 1-3. (B, C) Dorsal kinety 3 undergoes multiple fragmentation (arrowheads). (D-F) Loose kineties between kinety 3 and the rightmost fragment (arrowheads) align to form a row and newly formed dorsomarginal kineties shift to the dorsal surface. AZM = adoral zone of membranelles; CC $=$ caudal cirri; DK13 = dorsal kineties; DM1,2 = dorsomarginal kineties; MA = macronuclear nodules; $\mathrm{Ml}=$ micronuclei. Scale bars $=75 \mu \mathrm{m}$.

Nuclear division proceeds in the usual manner for oxytrichids. In middle dividers, the macronuclear nodules fuse to form a single mass which divides twice to produce the typical four nodules in late dividers (Fig. 5AF). The micronuclei undergo mitotic division in the usual manner. 

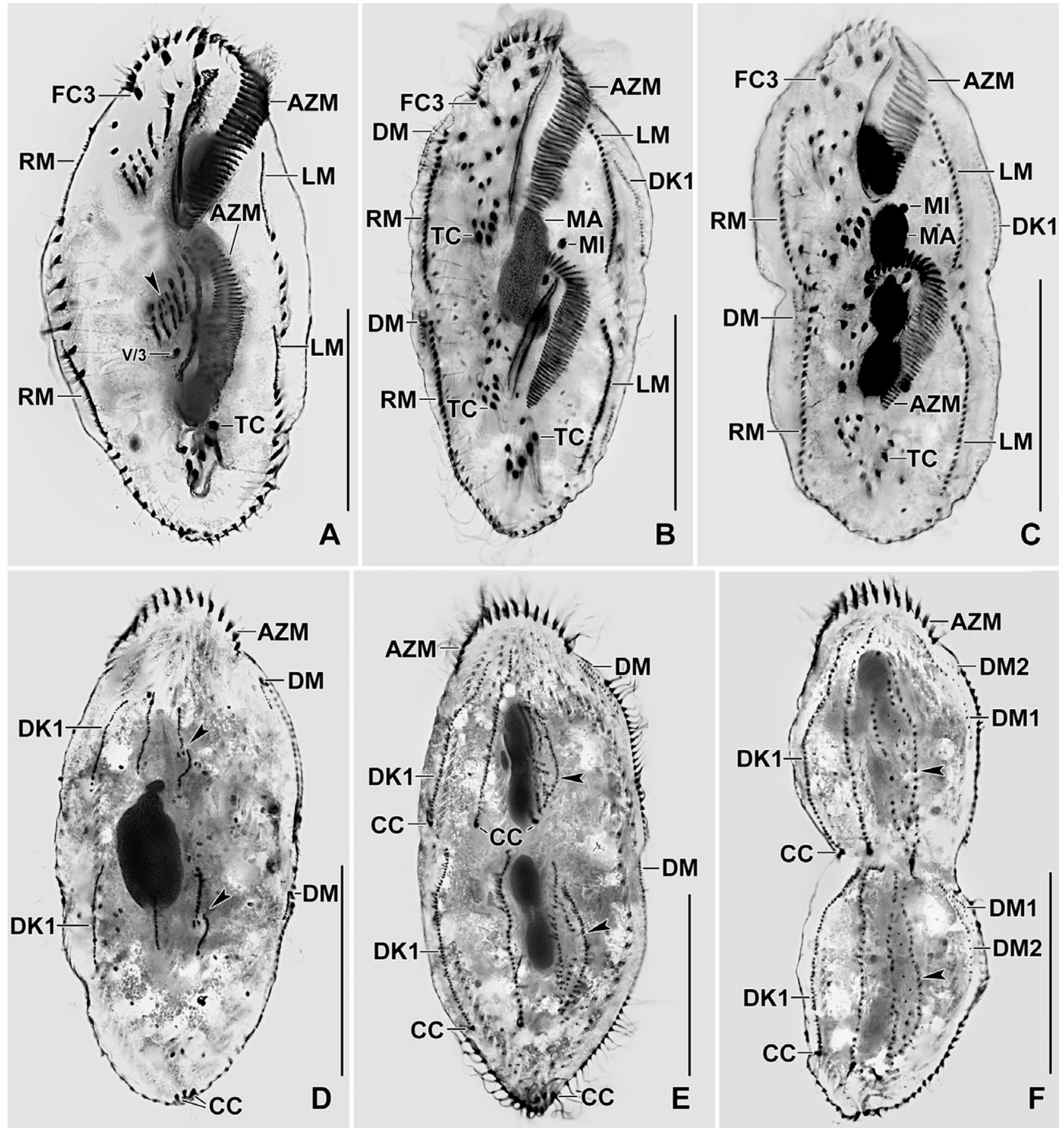

Figure 6 Photomicrographs of Rigidocortex quadrinucleatus after protargol impregnation. (A) The buccal and two parental frontoventral cirri disaggregate to form cirral streaks for the proter; two of the three postoral cirri transform to cirral anlagen for the opisthe; four anlagen for marginal cirri develop in proter and opisthe. The specimen shows additional anlage (arrowhead) which forms extra postoral ventral cirri. (B, C) Mid and late divider, showing the cirral and oral patterning and the origin of dorsomarginal kineties close to right marginal row. (D) Dorsal view of a mid-divider, showing within-row formation of the anlagen for dorsal kineties 1-3 and multiple fragmentation of kinety 3 (arrowheads). (E, F) Late dividers, showing the multiple spilt of the dorsal kinety 3 and the origin of caudal cirri at the end of kineties 1 and 2 and at the end of the right fragment of kinety 3 (arrowheads). Dorsomarginal kineties originate close to right marginal row. $\mathrm{AZM}=$ adoral zone of membranelles; $\mathrm{CC}=\mathrm{caudal}$ cirri; DK1 = dorsal kinety 1; DM1,2 = dorsomarginal kineties; $F C 3=$ frontal cirrus 3; $L M=$ left marginal row; $M A=$ macronuclear nodules; $M I=$ micronuclei; RM = right marginal row; $\mathrm{TC}=$ transverse cirri. Scale bars $=75 \mu \mathrm{m}$. 


\section{$\mathrm{BI} / \mathrm{ML}$}

0.09

A: Neokeronopsidae

B: Non-Stylonychine Oxytrichidae

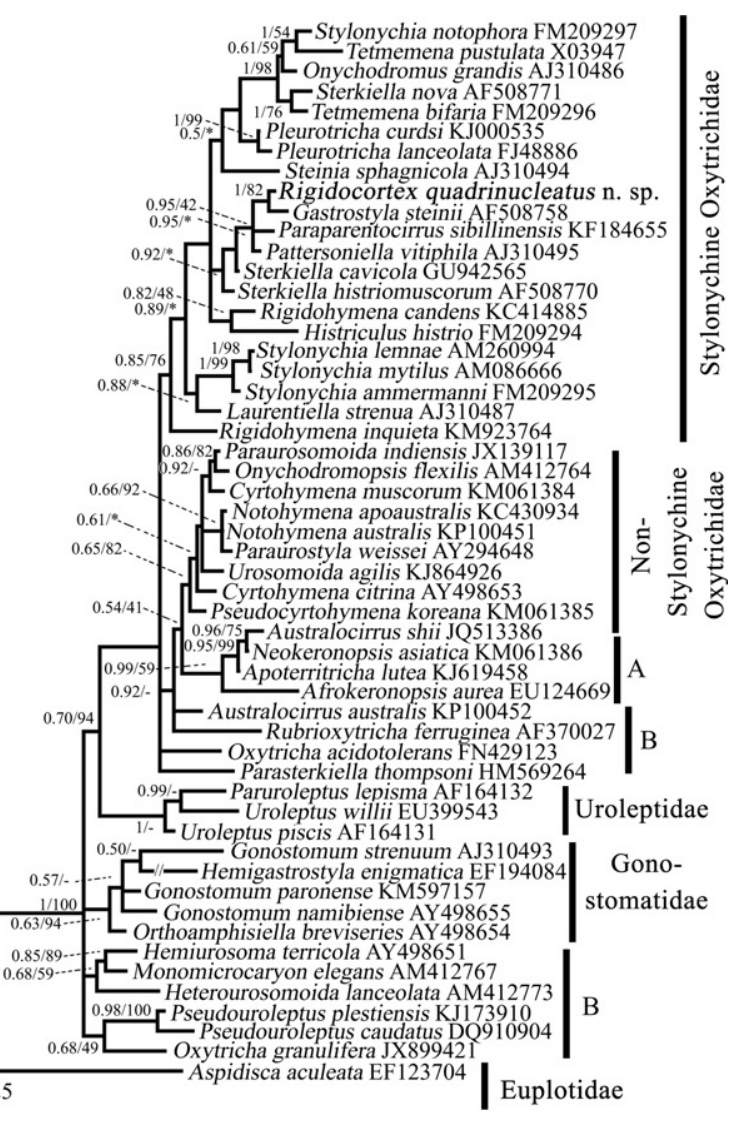

Figure 7 Bayesian tree inferred from the SSU rDNA sequences, showing the position of Rigidocortex quadrinucleatus (bold; accession number KX766184). Codes following the names are GenBank accession numbers. Numbers at the nodes represent the posterior probability of Bayesian analysis and the bootstrap values of maximum likelihood out of 1,000 replicates. A hyphen (-) represents minor differences between the Bayesian and $\mathrm{ML}$ tree topologies. Asterisk represents value lower than $40 \%$. The scale bar corresponds to nine substitutions per 100 nucleotide positions.

\section{$18 \mathrm{~S}$ rDNA sequence and phylogeny}

The SSU rDNA sequence of $R$. quadrinucleatus is $1,672 \mathrm{bp}$ in length and has a GC content of $44.74 \%$. It has been deposited in the $\mathrm{NCBI}$ database under the accession number KX766184. Phylogenetic trees inferred from the SSU rDNA sequences using $\mathrm{BI}$ and $\mathrm{ML}$ present similar topologies; therefore, only the $\mathrm{Bl}$ tree is shown here (Fig. 7). Phylogenetic analyses consistently place the new species within the stylonychine oxytrichids, clustering in a clade with Gastrostyla steinii.

\section{DISCUSSION}

\section{Comparison of Rigidocortex quadrinucleatus $\mathrm{n}$. sp. with related species}

In terms of the number of macronuclear nodules, cirral pattern and dorsal ciliature, Rigidocortex quadrinucleatus should be compared with R. octonucleatus (Foissner, 1988) Berger, 1999; Sterkiella cavicola (Kahl, 1935) Foissner et al., 1991, S. tetracirrata Kumar et al. 2015; S. admirabilis (Foissner, 1980) Berger, 1999; S. quadrinucleatus
(Sick, 1993) Berger, 1999; S. terricola Berger, 1999, and Gastrostyla steinii Engelmann, 1862.

Rigidocortex quadrinucleatus can be separated from the only congener $R$. octonucleatus mainly by the number of macronuclear nodules (4 vs. 8) (Berger 1999). Furthermore, the fragmentation of dorsal kinety 3 in R. octonucleatus is distinctly more pronounced than in R. quadrinucleatus.

Based on the nuclear apparatus and ventral ciliature $R$. quadrinucleatus can most likely be mistaken with S. cavicola. However, the difference in the dorsal ciliature (multiple vs. simple fragmentation) separates the two; a minor difference is the higher number of cirri (21 vs. 27) in left marginal row that runs along the posterior cell margin in $R$. quadrinucleatus. Sterkiella tetracirrata can be distinguished from $R$. quadrinucleatus in having a smaller body (85-110 vs. 155-215 $\mu \mathrm{m})$ and a lower number of transverse cirri (invariably 4 vs. 5) (Kumar et al. 2015). Sterkiella admirabilis can be easily separated from $R$. quadrinucleatus by having a significantly longer body in vivo $(350 \times 450 \mu \mathrm{m}$ vs. $180 \times 80 \mu \mathrm{m})$. Sterkiella quadrinucleatus differs from $R$. quadrinucleatus in having a marine or brackish (vs. soil) habitat (Berger 1999). 
Sterkiella terricola can be separated from $R$. quadrinucleatus in having only three (vs. 5) transverse cirri (Berger 1999).

Rigidocortex quadrinucleatus differs from G. steinii in the number of ventral cirri (18 vs. > 20) and dorsal kinety fragmentation (multiple vs. simple) (Berger 1999).

\section{Notes on the genus Rigidocortex}

Among oxytrichid ciliates, the flexibility/rigidity of body and the participation of the postoral ventral cirrus V/3 in anlagen formation were suggested as apomorphic characters by Berger and Foissner (1997) and Berger (1999). They divided the 18-cirri oxytrichids into the Stylonychinae (i.e., rigid body, lack of cortical granules, cirrus $V / 3$ not involved in primordia formation) and Oxytrichinae (i.e., flexible body, cirrus V/3 involved in primordia formation). The ontogenetic data of the present species clearly show that cirrus $V / 3$ is not involved in anlagen formation, thus supports the classification made by Berger (1999), i.e., transfer of A. octonucleatus to the new genus Rigidocortex. An improved diagnosis including morphogenetic data follows as: Rigid oxytrichid with typical 18 fronto-ventral-transverse cirri. One right and one left row of marginal cirri. Undulating membrane in Australocirrus pattern. More than six dorsal kineties due to multiple fragmentation of dorsal kinety 3 and two dorsomarginal rows. Caudal cirri present. Cirrus V/3 not involved in anlagen formation.

\section{Phylogenetic position of Rigidocortex quadrinucleatus} Phylogenetic analyses place $R$. quadrinucleatus close to G. steinii. This relationship is fully supported by a posterior probability of 1.00 , but less supported by $82 \% \mathrm{ML}$ bootstrap values (Fig. 7). Although these two genera differ in their cirral pattern, it has been reported that the high number of fronto-ventral-transverse (FVT) cirri in Gastrostyla and the individual cirral groups of 18-FVT cirri hypotrichs (e.g., Stylonychia, Sterkiella, Tetmemena, Histriculus etc.) are homologous (Berger 2008). Furthermore, R. quadrinucleatus and $G$. steinii exhibit similarities in the structure of resting cyst (wrinkled surface) and the number (invariably four) of macronuclear nodules. Our analyses also show that $R$. quadrinucleatus clusters away from the rather similar S. cavicola; from which it mainly differs morphologically by the presence (vs. absence) of multiple fragmentation of dorsal kinety 3. In this regard, it should be noted that the multiple fragmentation of dorsal kineties occurs also in other rigid genera, e.g., Pattersoniella Foissner, 1987; Laurentiella Dragesco and Njine, 1971, Onychodromus Stein, 1859. However, no significant relationship between these genera (except for all those belonging to the Stylonychinae) was reflected in the phylogenetic analyses suggesting, and as mentioned by Berger and Foissner (1997) and Berger (1999), that this feature evolved convergently.

Nonetheless, the results of our phylogenetic analyses should be taken cautiously, as future addition of further $18 S$ rDNA sequences from novel species within this group including the type species ( $R$. octonucleatus), might change the tree topology.

\section{Notes on the MOSYSS project and soil ciliates diversity in Italian agroecosystems}

The MOSYSS (MOnitoring SYstem of Soils at multiScale)_ Monitoring system of physical, chemical and biological soil parameters in relation to forest and agricultural land management, is an innovative project aimed to create a permanent soil monitoring system in the Marche Regions, Italy (Tiberi et al. 2014). The general aim was to increase the knowledge of regional soils, in order to allow a better protection of agricultural soils and sustainable land use. The project was started in 2010 by the Agriculture, Forest and Fisheries Department of the Marche Region, and was coordinated by the Regional Soil Observatory as a part of assessment activities of the Rural Development Plan (RDP; Marche, 2007-2013).

The main activities of the project were to analyze the chemical (i.e., pH, salinity, organic matter content, NPK availabilities, Cation Exchange Capacity), physical (i.e., bulk density, porosity, texture, compaction) and biological (i.e., indicators of biodiversity such as species richness and abundance of soil micro- and meso-organisms communities) properties of agricultural soils in order to obtain an evaluation of their current "quality/health" status, as well as to monitor, over time, changes in these parameters. The main activity of our group within the framework of the MOSYSS program was to investigate the community structures of two distinct soil taxa, i.e., the ciliated protists and the microarthropods (i.e., Acari, Collembola, Diplura, Symphyla, Diplopoda, Protura etc.). To the best of our knowledge, this is the first time that this combination of bioindicators has been used in soil monitoring plans (Antonietta La Terza, Santosh Kumar, Daizy Bharti, Silvia Marinsalti and Emilio Insom, unpub. results). Moreover, both taxa were recently included in a list of bioindicators appropriate for European soil monitoring (Stone et al. 2016).

In contrast to microarthropods, which have been widely used as bioindicators in Europe using the Biological SoilQuality (BSQ- ar) Index based on arthropods (Parisi et al. 2005), the use of ciliates is less common, in spite of the fact that they play a key role in soil microbial food webs by mediating the fluxes of nutrients and energy between different trophic levels (Geisen 2016). In this scenario, soil biomonitoring projects including ciliates offer not only the opportunity to assess the potential of ciliates as bioindicators of soil quality but also explore in detail their diversity, allowing discovery of new species/genera. A total of 30 selected sites (farms), scattered across the whole Marche Region, Italy, representing two main regional Management Systems (MS1: arable crop rotation excluding fodder; MS2: arable crop rotation including fodder) were qualitatively and quantitatively investigated for ciliates diversity twice in autumn 2012 and spring 2013 at the same topographic positions.

Overall, the results of our surveys conducted in the frame of MOSYSS (Marche Region: Kumar et al. 2014), Soil Mapping (Lombardia: Kumar et al. 2016; Bharti et al. 2015, 2016; La Terza et al. 2015) and Bioprint (UmbriaMarche: Bharti et al. 2014) projects confirmed the 
bioindicative potential of soil ciliate communities in discriminating different farm management systems and land uses (Antonietta La Terza, Santosh Kumar, Daizy Bharti, Silvia Marinsalti and Emilio Insom, unpubl. results). Furthermore, these studies have contributed to "reboot" soil ciliate diversity studies in Italy by updating Italian checklist, identifying more than 25 novel genera/species (yet to be described), and dwelling deeper into the "soil ciliate diversity black box" in agroecosystems.

\section{TAXONOMIC SUMMARY}

Family Oxytrichidae Ehrenberg, 1838

Genus Rigidocortex Berger, 1999

\section{Rigidocortex quadrinucleatus $\mathrm{n}$. sp.}

(Fig. 1A-G, 2A-C, 3A-E, 4A-G, 5A-F, 6A-F and Table 1) Diagnosis. Size on average $180 \times 80 \mu \mathrm{m}$ in vivo; body ellipsoidal to elongate ellipsoidal. Nuclear apparatus composed of four ellipsoidal macronuclear nodules and three micronuclei. Usually 18 fronto-ventral-transverse cirri. Right and left marginal row composed of an average of 25 and 27 cirri, respectively. Adoral zone $45 \%$ of body length and composed of an average of 44 membranelles. Seven dorsal kineties; three narrowly spaced, inconspicuous caudal cirri in body's midline. Resting cyst with wrinkled surface.

Type locality. Soil from an organic farm (site 209BIO; $\left.43^{\circ} 19^{\prime} 2.31^{\prime \prime} \mathrm{N} ; 1^{\circ} 27^{\prime} 51.89^{\prime \prime} \mathrm{E}\right)$ in the framework of the MOSYSS project, Marche Region, Italy. The farm is located in Contrada Fonte S. Giuliano, next to the city of Macerata at an elevation of $148 \mathrm{~m}$ a.s.l.

Type material. The protargol slide with the holotype specimen (Fig. 2B) circled in black ink is deposited in the Natural History Museum, London, U.K., with registration number NHMUK 2016.12.7.1. In addition, the slide contains many paratype specimens, with relevant cells marked by a black ink circle on the cover glass.

Etymology. The species-group name is a composite of the Latin adjective quadrus (four), vocalization vowel " $i$ " and the Latin adjective nucleatus (nuclear), referring to the four macronuclear nodules.

Occurrence and ecology. As yet found only at the type location. At the time of sampling, the BIO209 site was cultivated with fava beans (Vicia faba L.). The field was cultivated with wheat (Triticum aestivum L.) in the previous year. The main soil physico-chemical parameters that were measured at the time of sampling were as follows: soil moisture, $27.8 \%$; soil temperature $(5 \mathrm{~cm}), 20.4{ }^{\circ} \mathrm{C}$; soil pH, 8.3; organic carbon, $6.8 \mathrm{~g} / \mathrm{kg}$; total nitrogen, $0.8 \mathrm{~g} / \mathrm{kg}$; exchangeable $\mathrm{Ca}^{2+}, 3,269 \mathrm{mg} / \mathrm{kg}$; exchangeable $\mathrm{K}^{+}, 146$ $\mathrm{mg} / \mathrm{kg}$; exchangeable $\mathrm{Mg}^{2+}, 212 \mathrm{mg} / \mathrm{kg}$; exchangeable $\mathrm{Na}^{+}, 44 \mathrm{mg} / \mathrm{kg}$; cation exchange capacity, $17.8 \mathrm{meq} /$ $100 \mathrm{~g} ;$ and C/N ratio, 9:1. Soil texture: Sandy Clay Loam.

Gene sequence. The SSU rDNA sequence of Rigidocortex quadrinucleatus $\mathrm{n}$. $\mathrm{sp}$. has been deposited in the NCBI database under the accession number KX766184.

Zoobank registration. Zoobank registration number of the present work is: urn:Isid:zoobank.org:act:DB1409E5B53A-4F21-AE86-6A96CB4A6D0E.

\section{ACKNOWLEDGMENTS}

This study is part of a larger project denominated as "MOSYSS" (MOnitoring SYstem of Soils at multiScale) that was funded by Marche Region to ALT and from which financial support was provided to the co-authors DB and SK. The authors wish to greatly thank Dr. Silvia Marinsalti and Prof. Emilio Insom, School of Bioscience and Veterinary Medicine, University of Camerino (Italy) for help in sampling and for supporting us through all the stages of the research. The authors would like to thank Dr. Mauro Tiberi, Dr. Giovanni Ciabocco, and Dr. Cristina Bernacconi from the Regional Soil Observatory (http://suoli.regione.marche.it/) for their help in sampling and for sharing the chemical-physical data. A special thanks to Michael Gruber, Hieronymus-illustrations, for providing technical assistance. Furthermore, a great thank to all farmers for having facilitated and supported the research on their lands. Finally, the authors wish to greatly thank two anonymous reviewers and $A E$ for improving a first version of the manuscript with their helpful suggestions and constructive criticisms.

\section{LITERATURE CITED}

Berger, H. 1999. Monograph of the Oxytrichidae (Ciliophora, Hypotrichia). Monogr. Biol., 78:1-1080.

Berger, H. 2008. Monograph of the Amphisiellidae and Trachelostylidae (Ciliophora, Hypotricha). Monogr. Biol., 88:1-737.

Berger, H. \& Foissner, W. 1997. Cladistic relationships and generic characterization of oxytrichid hypotrichs (Protozoa, Ciliophora). Arch. Protistenkd., 148:125-155.

Bharti, D., Kumar, S. \& La Terza, A. 2014. Morphology, morphogenesis and molecular phylogeny of a novel soil ciliate, Pseudouroleptus plestiensis n. sp. (Ciliophora, Oxytrichidae), from the uplands of Colfiorito, Italy. Int. J. Syst. Evol. Microbiol., 64:2625-2636.

Bharti, D., Kumar, S. \& La Terza, A. 2015. Two gonostomatid ciliates from the soil of Lombardia, Italy; including note on the soil mapping project. J. Eukaryot. Microbiol., 62:762-772.

Bharti, D., Kumar, S. \& La Terza, A. 2016. Rigidosticha italiensis n. gen., n. sp. (Ciliophora, Spirotricha), a novel large hypotrich ciliate from the soil of Lombardia, Italy. Eur. J. Protistol., 56:112-118.

Castresana, J. 2000. Selection of conserved blocks from multiple alignments for their use in phylogenetic analysis. Mol. Biol. Evol., 17:540-552.

Foissner, W. 1987. Soil protozoa: fundamental problems, ecological significance, adaptations in ciliates and testaceans, bioindicators, and guide to the literature. Prog. Protistol., 2:69-212.

Foissner, W., Agatha, S. \& Berger, H. 2002. Soil ciliates (Protozoa, Ciliophora) from Namibia (Southwest Africa), with emphasis on two contrasting environments, the Etosha region and the Namib desert. Part I: text and line drawings. Part II: photographs. Denisia, 5:1-1459.

Foissner, W. \& Berger, H. 1999. Identification and ontogenesis of the nomen nudum hypotrichs (Protozoa: Ciliophora) Oxytricha nova (=Sterkiella nova sp. n.) and O. trifallax (=S. histriomuscorum). Acta Protozool., 38:215-248.

Geisen, S. 2016. The bacterial-fungal energy channel concept challenged by enormous functional versatility of soil protists. Soil Biol. Biochem., https://doi.org/10.1016/j.soilbio.2016.06. 013 
Glez-Peña, D., Gómez-Blanco, D., Reboiro-Jato, M., Fdez-Riverola, F. \& Posada, D. 2010. ALTER: program-oriented format conversion of DNA and protein alignments. Nucleic Acids Res., 38 (Suppl. 2):W14-W18.

Hadley, A. 2010. Combine ZP software, new version. (www documents), Available from URL: http://www.hadleyweb.pwp.blue yonder.co.uk/CZP/News.htm. (accessed 8 August 2016).

Kamra, K. \& Sapra, G. R. 1990. Partial retention of parental ciliature during morphogenesis of the ciliate Coniculostomum monilata (Dragesco and Njiné, 1971) Njiné, 1978 (Oxytrichidae, Hypotrichida). Eur. J. Protistol., 25:264-278.

Katoh, K. \& Standley, D. M. 2013. MAFFT multiple sequence alignment software version 7: improvements in performance and usability. Mol. Biol. Evol., 30:772-780.

Kumar, S., Bharti, D., Marinsalti, S., Insom, E. \& La Terza, A. 2014. Morphology, morphogenesis, and molecular phylogeny of Paraparentocirrus sibillinensis n. gen., n. sp., a "Stylonychine Oxytrichidae" (Ciliophora, Hypotrichida) without transverse cirri. J. Eukaryot. Microbiol., 61:247-259.

Kumar, S., Bharti, D., Quintela-Alonso, P., Shin, M. K. \& La Terza, A. 2016. Fine-tune investigations on three stylonychid (Ciliophora, Hypotricha) ciliates. Eur. J. Protistol., 56:200-218.

Kumar, S., Kamra, K., Bharti, D., La Terza, A., Sehgal, N., Warren, A. \& Sapra, G. R. 2015. Morphology, morphogenesis, and molecular phylogeny of Sterkiella tetracirrata n. sp. (Ciliophora, Oxytrichidae), from the Silent Valley National Park, India. Eur. J. Protistol., 51:86-97.

La Terza, A., Bharti, D., Kumar, S., Marinsalti, S., Molina, M. G. \& Insom, E. 2015. Struttura delle comunità dei protozoi ciliati. In: Beone, G. M., Cenci, R. M., Guidotti, L., Sena, F. \& Umlauf, G. (ed.), Progetto di Monitoraggio Ambientale su Tutto il Territorio Della Regione Lombardia (Progetto Soil): Indagine conoscitiva della qualità e dello stato di salute dei suoli lombardi, Report EUR 27161 IT. Publications Office of the European Union, Luxembourg. p. 259-271.

Medlin, L., Elwood, H. J., Stickel, S. \& Sogin, M. L. 1988. The characterization of enzymatically amplified eukaryotic 16S-like rRNAcoding regions. Gene, 71:491-499.

Parisi, V., Menta, C., Gardi, C., Jacomini, C. \& Mozzanica, E. 2005. Microarthropod communities as a tool to assess soil quality and biodiversity: a new approach in Italy. Agric. Ecosyt. Environ., 105:323-333.

Posada, D. 2008. jModelTest: phylogenetic model averaging. Mol. Biol. Evol., 25:1253-1256.

Ronquist, F. \& Huelsenbeck, J. P. 2003. MRBAYES 3: Bayesian phylogenetic inference under mixed models. Bioinformatics, 19:1572-1574.

Stone, D., Ritz, K., Griffiths, B. G., Orgiazzi, A. \& Creamer, R. E. 2016. Selection of biological indicators appropriate for European soil monitoring. Appl. Soil Ecol., 97:12-22.

Tamura, K., Peterson, D., Peterson, N., Stecher, G., Nei, M. \& Kumar, S. 2011. MEGA5: molecular evolutionary genetics analysis using maximum-likelihood, evolutionary distance, and maximum parsimony methods. Mol. Biol. Evol., 28:2731-2739.

Tiberi, M., Ciabocco, G., Bernacconi, C., Bampa, F., Dunbar, M. B. \& Montanarella, L. 2014. MOSYSS (MOnitoring SYStem of Soils at multiScale) - Monitoring system of physical, chemical and biological soil parameters in relation to forest and agricultural land management. Report EUR 26386 EN, Publications Office of the European Union, Luxembourg, pp. $1-136$.

Wallengren, H. 1900. Zur Kenntnis der vergleichenden Morphologie der hypotrichen Infusorien. Bih. K. Svensk Vetensk. Akad. Handl., 26:1-31. 